\title{
IL-1 Produced and Released Endogenously within Human Islets Inhibits $\beta$ Cell Function
}

\author{
Marc Arnush, ${ }^{\star}$ Monique R. Heitmeier, ${ }^{\star}$ Anna L. Scarim, ${ }^{\star}$ Margaret H. Marino, ${ }^{\ddagger}$ Pamela T. Manning, ${ }^{\S}$ and John A. Corbett* \\ *Edward A. Doisy Department of Biochemistry and Molecular Biology, St. Louis University School of Medicine, St. Louis, Missouri \\ 63104; and ${ }^{\ddagger}$ Department of Protein Biochemistry and ${ }^{\S}$ Department of Molecular Pharmacology, Inflammation Disease Research, G.D. \\ Searle, St. Louis, Missouri 63167
}

\begin{abstract}
Resident macrophages have been suggested to participate in the initiation of $\beta$ cell damage during the development of autoimmune diabetes. The purpose of this study was to determine if the endogenous production and release of interleukin 1 (IL-1) in human islets of Langerhans by resident macrophages results in the inhibition of $\beta$ cell function. Treatment of human islets with a combination of tumor necrosis factor (TNF) + lipopolysaccharide (LPS) + interferon- $\gamma($ IFN- $\gamma)$ stimulates inducible nitric oxide synthase (iNOS) expression, nitric oxide production, and inhibits glucose-stimulated insulin secretion. The IL-1 receptor antagonist protein (IRAP) prevents TNF + LPS + IFN- $\gamma$-induced iNOS expression and nitrite production, and attenuates the inhibitory effects on glucose-stimulated insulin secretion by human islets. Inhibition of iNOS activity by aminoguanidine also attenuates TNF + LPS + IFN- $\gamma$-induced inhibition of insulin secretion by human islets. These results indicate that the inhibitory effects of TNF + LPS + IFN- $\gamma$ are mediated by nitric oxide, produced by the actions of IL-1 released endogenously within human islets. Reverse transcriptase polymerase chain reaction was used to confirm that TNF + LPS + IFN- $\gamma$ stimulates the expression of both IL-1 $\alpha$ and IL-1 $\beta$ in human islets. Two forms of evidence indicate that resident macrophages are the human islet cellular source of IL-1: culture conditions that deplete islet lymphoid cells prevent TNF + LPS + IFN- $\gamma$-induced iNOS expression, nitric oxide production, and IL-1 mRNA expression by human islets; and IL-1 and the macrophage surface marker CD69 colocalize in human islets treated with TNF + LPS + IFN- $\gamma$ as determined by immunohistochemical analysis. Lastly, nitric oxide production is not required for TNF + LPS + IFN- $\gamma$-induced IL-1 release in human islets. However, cellular damage stimulates IL-1 release by islet macrophages. These findings support the hypothesis that activated islet macrophages may mediate $\beta$ cell damage during the development of insulin-dependent diabetes by
\end{abstract}

Address correspondence to Dr. Corbett, St. Louis University School of Medicine, Department of Biochemistry and Molecular Biology, 1402 South Grand Boulevard, St. Louis, MO 63104. FAX: 314-5778156; E-mail: corbettj@wpogate.slu.edu

Received for publication 6 June 1997 and accepted in revised form 28 May 1998.

J. Clin. Invest.

(c) The American Society for Clinical Investigation, Inc. 0021-9738/98/08/0516/11 \$2.00

Volume 102, Number 3, August 1998, 516-526

http://www.jci.org releasing IL-1 in human islets followed by cytokine-induced iNOS expression by $\beta$ cells. (J. Clin. Invest. 1998. 102:516526.) Key words: human islets - macrophages • inducible nitric oxide synthase $\bullet$ interleukin- 1 - insulin-dependent diabetes mellitus

\section{Introduction}

Insulin-dependent diabetes mellitus (IDDM) ${ }^{1}$ is characterized by a local inflammatory reaction in and around islets of Langerhans, followed by selective destruction of pancreatic islet $\beta$ cells. Resident macrophages have been proposed to be one islet cell type that may initiate $\beta$ cell damage during the development of autoimmune diabetes (1). Evidence to support this proposal includes studies showing that macrophage depletion by feeding a diet deficient in essential fatty acids (2) prevents the development of diabetes induced by multiple injections of streptozotocin in CD-1 mice, and attenuates the natural occurrence of diabetes in the Bio Breeding (BB) rat (3, 4). In addition, macrophage depletion by silica treatment attenuates the natural development of diabetes in BB rats (5). While these studies support a role for macrophage involvement in autoimmune diabetes, the mechanisms by which intraislet macrophages participate in the development of autoimmune diabetes are unknown.

In 1991, Lacy and Finke (6) showed that treatment of isolated islets with high concentrations of rat IFN- $\gamma$ resulted in islet destruction after a 4-7-d culture. Culturing islets for $7 \mathrm{~d}$ at $24^{\circ} \mathrm{C}$, a treatment that results in the depletion of $>98 \%$ of islet class II-positive lymphoid cells (presumed to be macrophages), prevents IFN- $\gamma$-induced islet destruction (6). Recently, we have shown that treatment of rat islets with TNF + LPS results in a potent inhibition of insulin secretion that is mediated by the intraislet release of IL-1, followed by IL-1-induced inducible nitric oxide synthase (iNOS) expression by $\beta$ cells (7). Although these studies indicate that islet lymphoid cells and the intraislet production of IL-1 can inhibit $\beta$ cell function, the extent to which resident human macrophages participate in the development of IDDM, and the mechanisms by which these cells mediate $\beta$ cell damage are unknown. In this study we have evaluated the effects of resident macrophage activation on $\beta$ cell function in human islets of Langerhans. We show that treatment of human islets with TNF + LPS + IFN- $\gamma$, conditions known to activate macrophages, results in the expression of iNOS, the increased production of nitric oxide, and a potent inhibition of insulin secretion. In addition, evidence is presented that supports TNF + LPS + IFN- $\gamma$-induced resident

1. Abbreviations used in this paper: AG, aminoguanidine; IDDM, insulin-dependent diabetes mellitus; iNOS, inducible nitric oxide synthase; IRAP, IL-1 receptor antagonist protein. 
macrophage expression and release of IL-1 in islets, followed by cytokine-induced inhibition of $\beta$ cell function as a mechanism by which resident macrophages mediate $\beta$ cell damage in human islets.

\section{Methods}

Materials. Human islets were provided by the Islet Isolation Core Facility at Washington University School of Medicine (St. Louis, MO) and the Diabetes Research Institute at the University of Miami (Miami, FL). Human recombinant IL-1 $\beta$ was from Cistron Biotechnology (Pine Brook, NJ). Human recombinant IFN- $\gamma$ and human recombinant TNF- $\alpha$ were from Boehringer Mannheim (Indianapolis, IN). Human recombinant IL-1 receptor antagonist protein (IRAP) was a gift from Dr. Charles Hall (Upjohn, Kalamazoo, MI). CMRL-1066 tissue culture medium, penicillin, streptomycin, L-glutamine, and all PCR oligonucleotide primers were from GIBCO BRL (Gaithersburg, MD). FCS was obtained from Hyclone Labs (Logan, UT). Aminoguanidine hemisulfate (AG) was from Sigma Chemical Co. (St. Louis, MO). ECL reagents were obtained from Amersham (Arlington Heights, IL). Horseradish peroxidase-conjugated donkey antirabbit IgG, FITC-conjugated donkey anti-guinea pig and donkey anti-mouse IgG, and CY3-conjugated donkey anti-rabbit and donkey anti-goat IgG were from Jackson ImmunoResearch Laboratories, Inc. (West Grove, PA). Affinity-purified goat anti-human IL-1 $\beta$ and mouse anti-human macrophage CD68 were from R\&D Systems (Minneapolis, MN) and Biomeda Corp. (Foster City, CA), respectively. Rabbit anti-human iNOS antiserum used in Fig. 1 was prepared as described previously (8). All other Western blots were performed with rabbit anti-human iNOS prepared against the COOH-terminal 19 amino acids of human iNOS (Santa Cruz Biotechnology, Santa Cruz, Ca). All other reagents were from commercially available sources.

Islet culture, lymphoid cell depletion, and insulin secretion. Freshly isolated human islets were cultured for $3 \mathrm{~d}$ at $37^{\circ} \mathrm{C}$ in complete CMRL-1066 (CMRL-1066 containing $2 \mathrm{mM}$ L-glutamine, 10\% heatinactivated FCS, $100 \mathrm{U} / \mathrm{ml}$ penicillin, and $100 \mu \mathrm{g} / \mathrm{ml}$ streptomycin) before experimentation. Resident lymphoid cells were depleted from human islets as previously described for rat islets (6). In brief, isolated human islets were cultured at $24^{\circ} \mathrm{C}$ in an atmosphere of $95 \%$ air and $5 \% \mathrm{CO}_{2}$ in complete CMRL-1066 tissue culture medium for $7 \mathrm{~d}$. Islets were removed from the $24^{\circ} \mathrm{C}$ culture, washed three times with fresh complete CMRL-1066, and were then cultured for $3 \mathrm{~d}$ at $37^{\circ} \mathrm{C}$ in complete CMRL-1066. Resident macrophage depletion was confirmed by immunohistochemical analysis of CD68-positive macrophages using methods outlined below. Glucose-stimulated insulin secretion by human islets, incubated for $40 \mathrm{~h}$ with the indicated concentrations of IRAP, IFN- $\gamma$, TNF, LPS, and AG, was performed as described previously (9). Where indicated, human islets were pretreated for $15 \mathrm{~min}$ with IRAP before incubation with cytokines and LPS.

Human islet dispersion. Isolated human islets were dispersed into individual cells by treatment with trypsin $(1.0 \mathrm{mg} / \mathrm{ml})$ in $\mathrm{Ca}^{2+}$ - and $\mathrm{Mg}^{2+}$-free Hanks' solution at $37^{\circ} \mathrm{C}(7,10)$. The dispersed islet cells were counted and immediately aliquoted into 24-well microtiter plates $(120,000$ cells/400 $\mu \mathrm{l}$ of complete CMRL-1066) and cultured for $1 \mathrm{~h}$. Experiments were initiated by the addition of cytokines as described above.

Western blot analysis and nitrite determination. iNOS protein expression was determined by Western blot analysis as described previously for human islets (8). Nitrite production was determined as described previously (11) by mixing $50-\mu l$ portions of culture media with $50 \mu 1$ of Griess reagent and the absorbance at $540 \mathrm{~nm}$ was determined.

Immunohistochemistry. Immunohistochemistry was performed as previously described for sequential double staining of intact rat islets (7). In brief, after cytokine stimulation, islets $(2,000 / 3 \mathrm{ml}$ of com- plete CMRL-1066) were isolated by centrifugation, washed three times in $0.1 \mathrm{M} \mathrm{PBS}, \mathrm{pH} 7.4$, and then fixed overnight in $2 \%$ paraformaldehyde in $0.1 \mathrm{M} \mathrm{PBS}$ at $4^{\circ} \mathrm{C}$. The islets were cryopreserved by incubation at $4^{\circ} \mathrm{C}$ in $0.1 \mathrm{M}$ PBS containing $10 \%$ sucrose. Sections were prepared $(\sim 8 \mu \mathrm{m})$ and sequentially stained for human iNOS using rabbit anti-human iNOS (1:500 dilution) and indocarbocyanine (CY-3)-conjugated donkey anti-rabbit secondary antiserum (1:200 dilution; red fluorescence), and insulin using guinea pig anti-human insulin (1:500 dilution) and FITC-conjugated donkey anti-guinea pig secondary antiserum (1:200 dilution; green fluorescence).

For immunohistochemical identification of IL-1-expressing cells, human islets (150/400 $\mu \mathrm{l}$ of complete CMRL-1066), cultured for $4 \mathrm{~h}$ with or without $50 \mathrm{ng} / \mathrm{ml} \mathrm{TNF}+10 \mu \mathrm{M} \mathrm{LPS}+750 \mathrm{U} / \mathrm{ml} \mathrm{IFN}-\gamma$, were isolated and dispersed into individual cells (see above). Islet cells were washed three times with $0.1 \mathrm{M}$ PBS ( $\mathrm{pH} 7.4$ ) and diluted to a concentration of 40,000 cells $/ 100 \mu$ l. The cells were transferred to Superfrost/Plus microscope slides by cytospin. The slides were fixed in $4 \%$ paraformaldehyde for $1 \mathrm{~h}$ at $4^{\circ} \mathrm{C}$ and then blocked for $1 \mathrm{~h}$ with $5 \%$ BSA (in $0.1 \mathrm{M}$ PBS). The slides were incubated overnight at room temperature with a 1:25 dilution (in $0.1 \mathrm{M}$ PBS containing $1 \%$ BSA) of goat anti-human IL-1 $\beta$ antiserum, followed by a 1-h incubation with a 1:100 dilution of mouse anti-human macrophage antiserum (CD68). The slides were washed three times with $150 \mu$ l of PBS and then incubated for $1 \mathrm{~h}$ with a 1:200 dilution of FITC-conjugated donkey anti-mouse and CY3-conjugated donkey anti-goat secondary antibody for IL-1 $\beta$ and CD68, respectively. Immunofluorescence microscopy was used for the detection of IL- $1 \beta$-expressing cells and CD68-positive macrophages.

$P C R$. Total RNA was isolated from islets using the Qiagen RNeasy RNA isolation kit. Total RNA $(2.5 \mu \mathrm{g})$ from each sample was then used to prepare first-strand cDNA with the GIBCO BRL Preamplification Superscript kit. A standard $25-\mu$ l PCR reaction containing $2.5 \mu \mathrm{l}$ from the RT reaction, $200 \mu \mathrm{M}$ each of dATP, dCTP, dGTP, and dUTP, 50 pmol each of forward and reverse primers, $2 \mathrm{U}$ of Taq DNA polymerase (Promega, Madison, WI), $1.5 \mathrm{mM} \mathrm{MgCl}_{2}$, and 2.5 $\mu \mathrm{l}$ of the supplied $10 \times$ reaction buffer was performed. IL- $1 \alpha$, IL- $1 \beta$, iNOS, and GAPDH primers used for PCR were: (a) IL-1 $\alpha$ forward primer 5'-CCACTCCATGAAGGCTGCATG-3', reverse primer 5'-GGTGCTGACCTAGGCTTGATG-3' (PCR product size $=204$ bp); (b) IL-1 $\beta$ forward primer 5'-CCTGTGGCCTTGGGCCTCAA3', reverse primer 5'-GGTGCTGATGTACCAGTTGGG-3' (PCR product size $=204 \mathrm{bp}) ;(c)$ iNOS forward primer $5^{\prime}$-ACATTGATCAGAAGCTGTCCCAC-3', reverse primer 5'-CAAAGGCTGTGAGTCCTGCAC-3' (PCR product size $=236 \mathrm{bp}) ;(d)$ GAPDH forward primer 5'-GCTGGGGCTCACCTGAAGGG-3', reverse primer 5'-GGATGACCTTGCCCACAGCC-3' (PCR product size = $343 \mathrm{bp})$.

Each PCR reaction mixture was overlaid with one drop of mineral oil, and then incubated in a thermal cycler using the following profile: an initial denaturation step at $94^{\circ} \mathrm{C}$ for $5 \mathrm{~min}$, followed by 30 cycles of $94^{\circ} \mathrm{C}$ for $45 \mathrm{~s}, 60^{\circ} \mathrm{C}$ for $45 \mathrm{~s}$, and $72^{\circ} \mathrm{C}$ for $75 \mathrm{~s}$. The samples were finally incubated at $30^{\circ} \mathrm{C}$ for $2 \mathrm{~min}$. To each reaction, $5 \mu \mathrm{l}$ of $6 \times$ loading dye (Promega) was added, and then $12 \mu \mathrm{l}$ from each PCR reaction was run alongside $5 \mu \mathrm{l}$ of $100 \mathrm{BP}$ marker (Promega) on a $1.5 \%$ agarose gel containing $0.5 \mu \mathrm{g} / \mathrm{ml}$ ethidium bromide. PCR products were visualized with ultraviolet light and photographed.

Semiquantitative PCR. cDNA prepared as described above was used for semiquantitative PCR as previously described $(12,13)$. In brief, each cDNA template was diluted 1:25 and 1:50 for both IL- $1 \alpha$ and IL-1 $\beta$ reactions, and 1:125 and 1:250 for GAPDH reactions. Therefore, amplification of each cDNA species for each sample was represented by two different concentrations of initial cDNA template. This would later be used to verify that each reaction was amplified in the linear range, and that PCR product yields were proportional to initial concentrations of cDNA template. From each cDNA dilution, $5 \mu \mathrm{l}$ was used in a standard $25-\mu \mathrm{l}$ PCR reaction as described above, and $2.5 \mu \mathrm{Ci}$ of $\left[\alpha{ }^{-32} \mathrm{P}\right] \mathrm{dCTP}$ was added. PCR was conducted according to the standard profile described above with the exception 
A

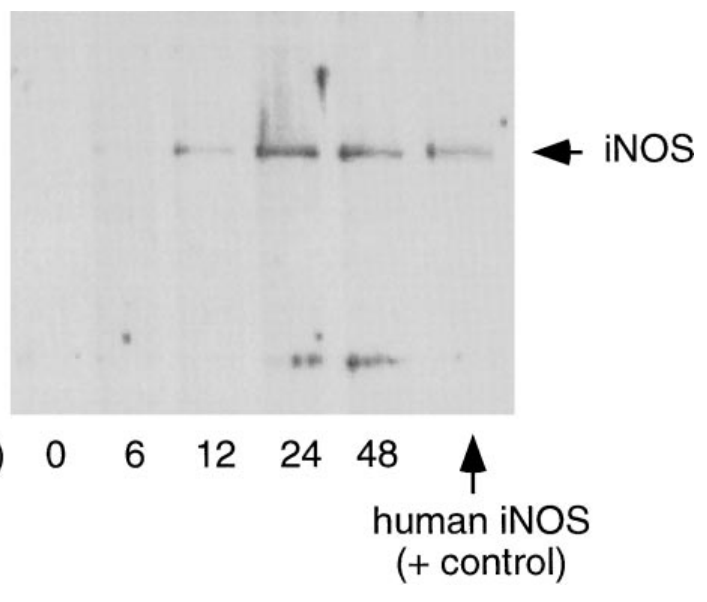

B

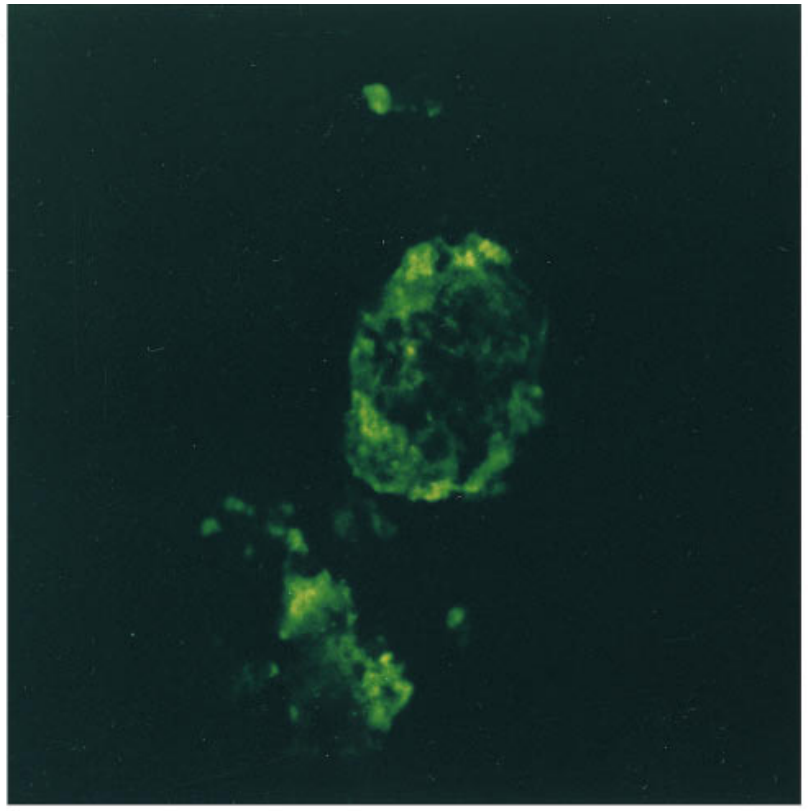

Figure 1. Time course of expression and cellular source of iNOS in human islets treated with IL- $1 \beta+$ IFN- $\gamma$. $(A)$ Freshly isolated human islets $(150 / 400 \mu$ l of complete CMRL-1066) were cultured for the indi-

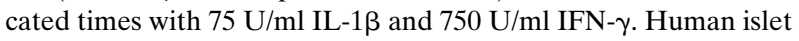
proteins were separated on $8 \%$ polyacrylamide SDS gels and iNOS expression was determined by Western blot analysis. $(B)$ For immunohistochemical detection of iNOS and insulin, $8-\mu \mathrm{m}$ frozen sections were prepared from human islets exposed to IL-1 + IFN- $\gamma$ for $40 \mathrm{~h}$. Insulin was detected with guinea pig anti-human insulin (1:500 dilution) and FITC-conjugated donkey anti-guinea pig secondary antiserum (1:200 dilution; green fluorescence). Human iNOS was detected with the same rabbit anti-human iNOS antiserum (1:500 dilution) used for Western blots shown in $A$, and indocarbocyanine (CY-3)-conjugated donkey anti-rabbit secondary antiserum (1:200 dilution; red fluorescence). Colocalization of insulin and iNOS results in an intense yellow fluorescence after double exposure. Results are representative of two independent experiments from two human islet isolations.

\section{Insulin}
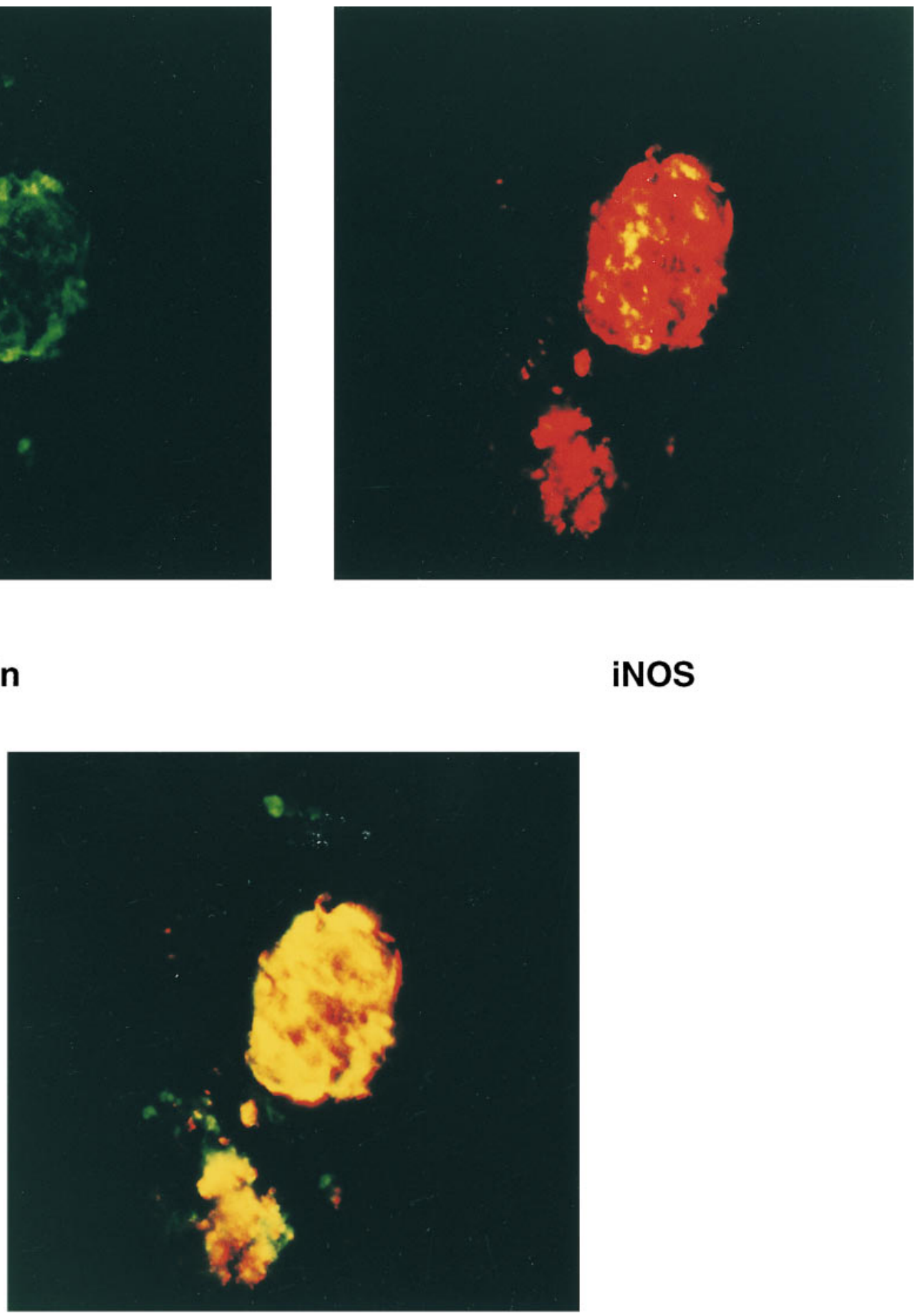

Insulin + iNOS 
of reducing the cycle number to 22 . From each PCR reaction $12 \mu \mathrm{l}$ was run on a $1.5 \%$ agarose gel, the gels were dried, and phosphorimage analysis was conducted using a PhosphorImager and ImageQuant Software version 3.3 (Molecular Dynamics, Inc., Sunnyvale, CA). The values obtained for each IL-1 PCR reaction were normalized as a percentage of the values obtained for each GAPDH control. Under the conditions used, the PCR product signal is proportional to the amount of cDNA subjected to PCR amplification.

Figure preparation. Ethidium-stained agarose gels and Western blot autoradiograms were scanned into NIH Image version 1.59 using a high performance CCD camera (COHU, Brookfield, WI). The images were then imported into Canvas 3.5 (Deneba Software, Miami, $\mathrm{FL}$ ) for the preparation of figures.

\section{Results and Discussion}

Human islet cellular source of $i N O S$. Our previous studies have identified IL-1 $\beta+$ IFN- $\gamma$ as the minimal combination of cytokines required to stimulate iNOS expression and nitric oxide production by human islets $(9,14)$. Alone, IL-1, TNF, or IFN- $\gamma$ does not stimulate iNOS expression by human islets, nor do the combinations of TNF + IFN- $\gamma$ or IL-1 + TNF $(9,14)$. As shown in Fig. $1 A$, treatment of human islets with $75 \mathrm{U} / \mathrm{ml}$ IL$1 \beta+750 \mathrm{U} / \mathrm{ml} \mathrm{IFN-} \gamma$ results in the time-dependent expression of iNOS that is first apparent after a 12-h exposure and maximal after a 24- and 48-h incubation. The cellular source of iNOS in human islets treated for $40 \mathrm{~h}$ with IL- $1 \beta+$ IFN- $\gamma$ was examined by immunohistochemical colocalization of iNOS and insulin (Fig. $1 B$ ). The combination of IL- $1 \beta+$ IFN- $\gamma$ stimulates high levels of iNOS expression in human islets (red fluorescence) and iNOS expression nearly completely colocalizes with insulin-containing cells (green) as evidenced by the intense yellow fluorescence upon double exposure. IL-1 + IFN- $\gamma$ also appear to stimulate iNOS expression in a number of islet cells that do not contain insulin. However, human $\beta$ cells release insulin in culture, thus it is not clear if these cells are $\beta$ cells with depleted insulin stores or if a second population of islet cells also expresses iNOS in response to this cytokine combination. In controls, iNOS expression was not detected in untreated human islets and staining was not observed using secondary antisera alone (data not shown). These findings indicate that $\beta$ cells are a cellular source of iNOS in human islets after treatment with IL- $1 \beta+$ IFN- $\gamma$.

$T N F+L P S+I F N-\gamma$-induced iNOS expression and nitrite production by human islets requires the intraislet release of $I L-1$. Treatment of rat islets with TNF + LPS results in a potent inhibition of insulin secretion that is mediated by the in-
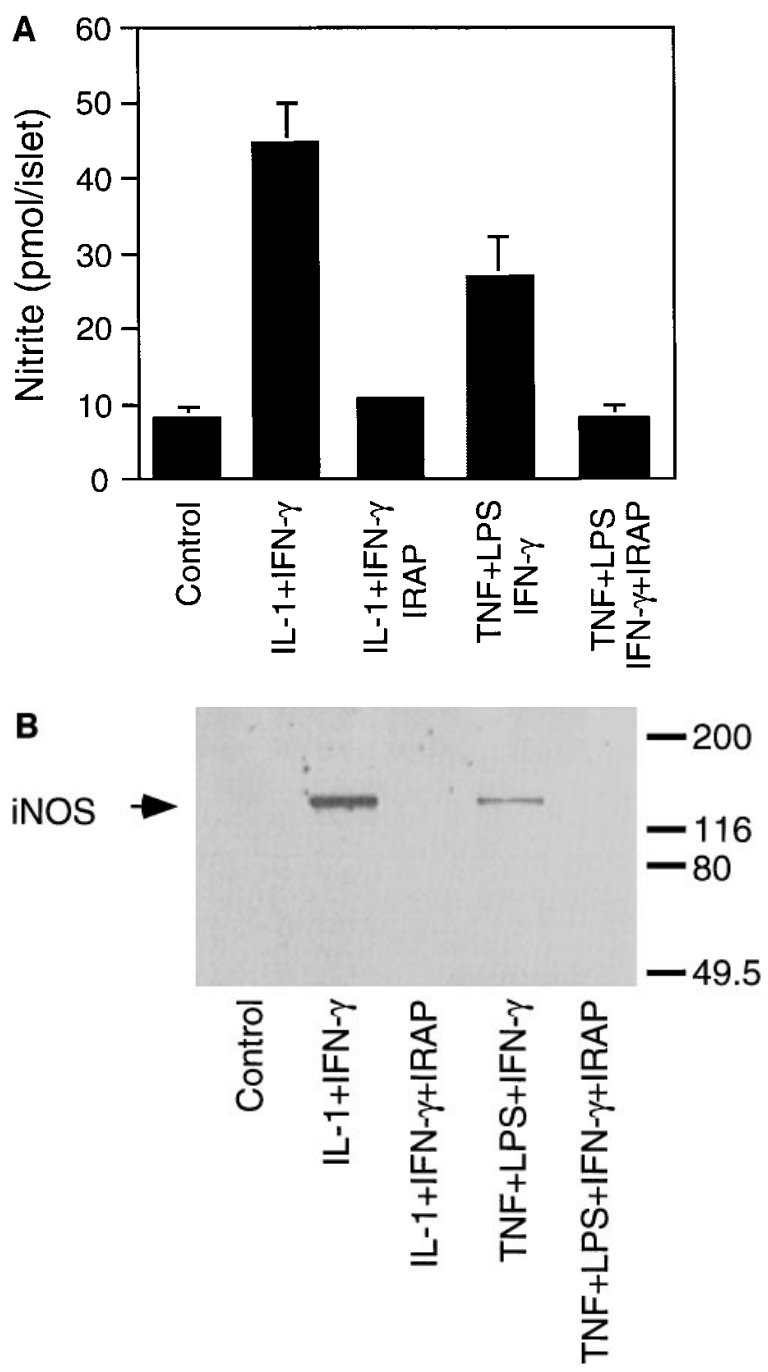

C

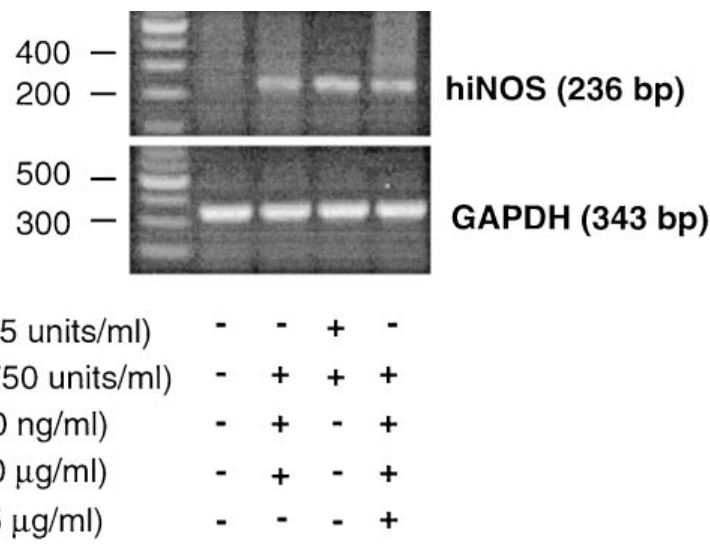

Figure 2. Effects of intraislet release of IL-1 on nitrite production and iNOS expression by human islets. Human islets $(150 / 400 \mu \mathrm{l}$ of complete CMRL1066) were treated for $40 \mathrm{~h}$ with $75 \mathrm{U} / \mathrm{ml} \mathrm{IL}-1,750 \mathrm{U} / \mathrm{ml} \mathrm{IFN}-\gamma, 50 \mathrm{ng} / \mathrm{ml}$ TNF- $\alpha, 10 \mu \mathrm{g} / \mathrm{ml}$ LPS, and $5 \mu \mathrm{g} / \mathrm{ml}$ human recombinant IRAP at $37^{\circ} \mathrm{C}$ as indicated. $(A)$ After the treatment period, media were removed for nitrite determination, and $(B)$ the human islets were isolated and used to detect iNOS expression by Western blot analysis. (C) Human islets ( 80 islts $/ 400 \mu \mathrm{l}$ of complete CMRL-1066) were cultured for $8 \mathrm{~h}$ with the indicated concentrations of cytokines and LPS. Total RNA was isolated and iNOS mRNA expression was determined by RT-PCR. Nitrite data are the mean \pm SEM of four independent experiments from four separate human islet isolations. Western blot data are representative of four independent experiments from four separate human islet isolations. RT-PCR is representative of two independent experiments from two separate human islet isolations. 
traislet release of IL-1 followed by IL-1-induced iNOS expression by $\beta$ cells (7). Therefore, we examined the effects of $\mathrm{TNF}+$ LPS on iNOS expression and nitrite production by human islets. Either alone or in combination, TNF $(10 \mathrm{ng} / \mathrm{ml})+$ LPS $(10 \mu \mathrm{g} / \mathrm{ml})$ fail to stimulate iNOS expression or nitrite production by human islets after a 40-h exposure (data not shown). Since human $\beta$ cells require a combination of IL-1 + IFN- $\gamma$ to stimulate iNOS expression (Fig. 1), the lack of iNOS expression in response to TNF + LPS may be due to the absence of IFN- $\gamma$. Therefore, the effects of TNF + LPS + IFN- $\gamma$ on iNOS expression and nitrite production by human islets were examined. Incubation of human islets for $40 \mathrm{~h}$ with $\mathrm{TNF}+\mathrm{LPS}+\mathrm{IFN}-\gamma$ results in iNOS expression and a threefold increase in nitrite production (Fig. 2). IRAP $(5 \mu \mathrm{g} / \mathrm{ml})$ prevents TNF + LPS + IFN- $\gamma$-induced nitrite production and iNOS protein expression by human islets (Fig. 2, $A$ and $B$, respectively), indicating that iNOS expression and nitrite production require the intraislet release of IL-1. In addition, antisera specific for IL- $1 \alpha$ and IL- $1 \beta$ attenuate TNF + LPS + IFN- $\gamma$-induced nitrite formation and iNOS expression by human islets (data not shown).

TNF + LPS + IFN- $\gamma$ also stimulate the accumulation of iNOS mRNA by human islets after an 8-h exposure (Fig. $2 C$ ). Although IRAP prevents TNF + LPS + IFN- $\gamma$-induced iNOS protein expression and nitrite formation by human islets, this receptor antagonist does not inhibit iNOS mRNA accumulation under these conditions. We believe that resident macrophages may be the islet cellular source of iNOS mRNA that is stimulated by TNF + LPS + IFN- $\gamma$, and that it is insensitive to IRAP. Evidence to support this conclusion includes the finding that macrophage depletion by culturing islets for $7 \mathrm{~d}$ at $24^{\circ} \mathrm{C}$ prevents TNF + LPS + IFN- $\gamma$-induced iNOS mRNA expression (see Fig. $4 C$ ). In addition, IRAP has been shown to prevent TNF + LPS-induced iNOS protein expression by $\beta$ cells, but without inhibiting iNOS expression by a subpopulation of rat islet cells $(\sim 5-10 /$ islet $)$ believed to be resident macrophages (7). Thus, TNF + LPS + IFN- $\gamma$-induced iNOS expression and nitric oxide production by human islets appear to require the intraislet release of IL-1 followed by IL-1 + IFN$\gamma$-induced iNOS expression by $\beta$ cells. TNF + LPS + IFN- $\gamma$ also stimulate iNOS mRNA expression by a second population of cells believed to be resident macrophages.

$T N F+L P S+I F N-\gamma$-induced inhibition of insulin secretion is attenuated by IRAP and $A G$. To determine if $\beta$ cell function is inhibited by the endogenous production of IL-1 in human islets, the effects of TNF + LPS + IFN- $\gamma$ on glucosestimulated insulin secretion were examined. Treatment of human islets for $40 \mathrm{~h}$ with a combination of TNF + LPS + IFN- $\gamma$ results in $\sim 70 \%$ inhibition of glucose-stimulated insulin secretion (Fig. 3). The inhibitory effects of TNF + LPS + IFN- $\gamma$ on insulin secretion are attenuated by IRAP. This result supports the hypothesis that activation of resident islet macrophages results in an impairment of $\beta$ cell function by a mechanism that requires the intraislet release of IL-1. Also, the iNOS-selective inhibitor AG $(15,16)$ attenuates TNF + LPS + IFN- $\gamma$-induced inhibition of insulin secretion to levels that are comparable to those seen with IRAP. This result is consistent with our previous studies showing that IL- $1+\mathrm{TNF}+\mathrm{IFN}-\gamma$-induced inhibition of insulin secretion by human islets is attenuated by NMMA (9), and indicates that nitric oxide mediates, in part, the inhibitory effects of cytokines on human islet function. The lack of complete prevention of TNF + LPS + IFN- $\gamma$-induced

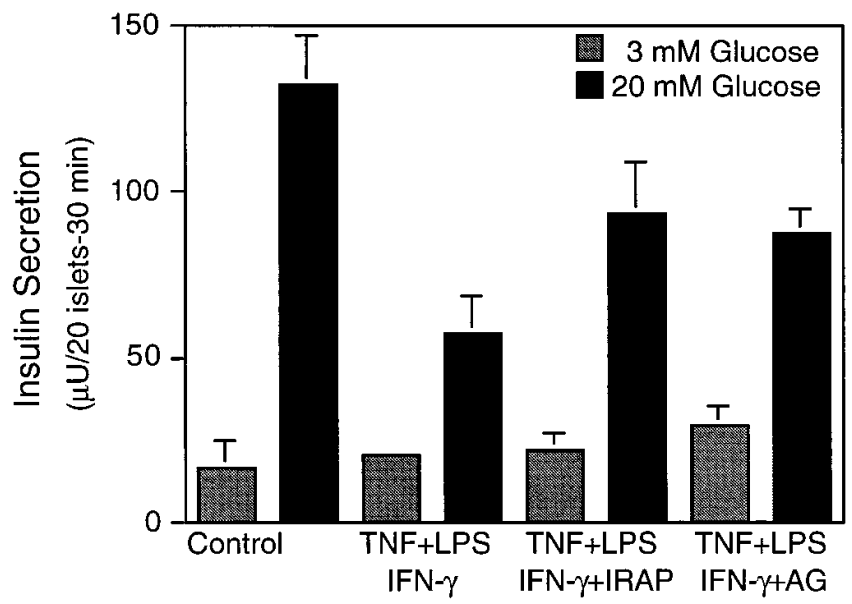

Figure 3. Effects of resident islet macrophage activation on glucosestimulated insulin secretion by human islets. Human islets $(220 / 1 \mathrm{ml}$ of complete CMRL-1066) were cultured for $40 \mathrm{~h}$ with $750 \mathrm{U} / \mathrm{ml}$ IFN- $\gamma, 50 \mathrm{ng} / \mathrm{ml}$ TNF- $\alpha, 10 \mu \mathrm{g} / \mathrm{ml} \mathrm{LPS}, 5 \mu \mathrm{g} / \mathrm{ml}$ IRAP, and $1 \mathrm{mM}$ AG as indicated. The islets were isolated and glucose-stimulated insulin secretion was examined as described in Methods. Results are the mean \pm SEM of four independent experiments containing three to four replicates per condition from four independent human islet isolations.

inhibition of insulin secretion by either IRAP or AG suggests that nitric oxide may not be the only effector molecule that participates in the inhibition of $\beta$ cell secretory function under these conditions.

Lymphoid cell depletion attenuates TNF + LPS $+I F N-\gamma$ induced iNOS expression by human islets. Results from Figs. 2 and 3 indicate that TNF + LPS + IFN- $\gamma$ stimulate iNOS expression and inhibit insulin secretion by a mechanism that requires the endogenous production and release of IL-1 in human islets. To determine if resident macrophages are an islet source of IL-1, the effects of TNF + LPS + IFN- $\gamma$ on nitrite production and iNOS expression by human islets depleted of resident macrophages have been evaluated. The combination of TNF + LPS + IFN- $\gamma$ fails to stimulate nitrite production or iNOS protein expression by human islets cultured for $7 \mathrm{~d}$ at $24^{\circ} \mathrm{C}$ (Fig. 4, $A$ and $B$ ). Low levels of iNOS mRNA are detected under these conditions (Fig. $4 C$ ). However, the level of expression is considerably reduced as compared with iNOS expression by freshly isolated human islets (Fig. $2 \mathrm{C}$ ). In addition, a $7-\mathrm{d}$ culture at $24^{\circ} \mathrm{C}$ does not inhibit $\beta$ cell function as IL-1 $\beta+$ IFN- $\gamma$ stimulate the expression of iNOS and production of nitrite to levels nearly equivalent to those produced by freshly isolated human islets (Figs. 2 and 4). These results show that a 7 -d culture at $24^{\circ} \mathrm{C}$ does not inhibit $\beta$ cell expression of iNOS (in response to IL-1 + IFN- $\gamma$ ) but prevents iNOS expression stimulated by the intraislet release of IL-1 (TNF + LPS + IFN- $\gamma$ ), and provides evidence to suggest that resident macrophages are a cellular source of IL-1 in human islets.

To confirm that a $7-\mathrm{d}$ culture at $24^{\circ} \mathrm{C}$ depletes human islets of resident macrophages, the effects of this culture condition on the presence of resident macrophages was examined by immunohistochemistry. For these experiments, islets either freshly isolated or cultured for $7 \mathrm{~d}$ at $24^{\circ} \mathrm{C}$ were dispersed into individual cells and plated onto slides by cytospin. The number 

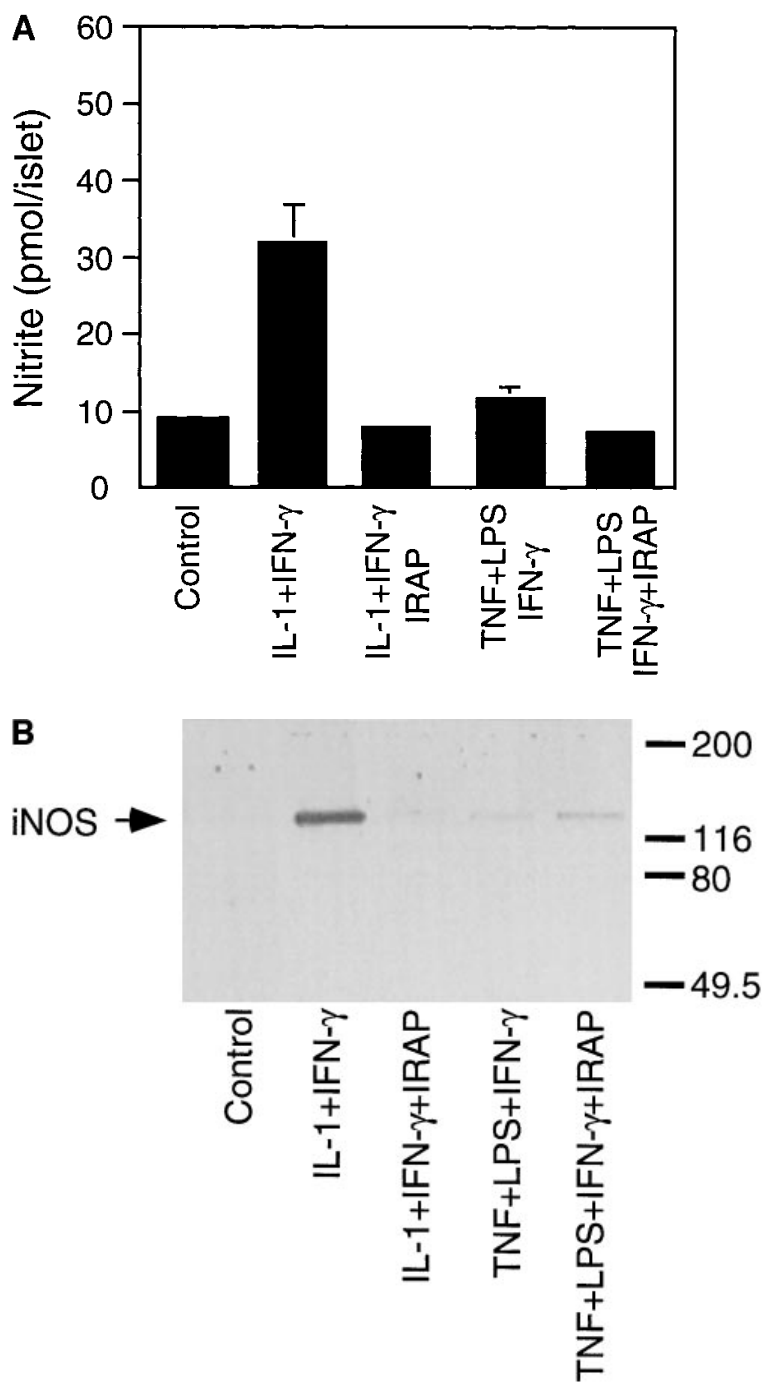

C
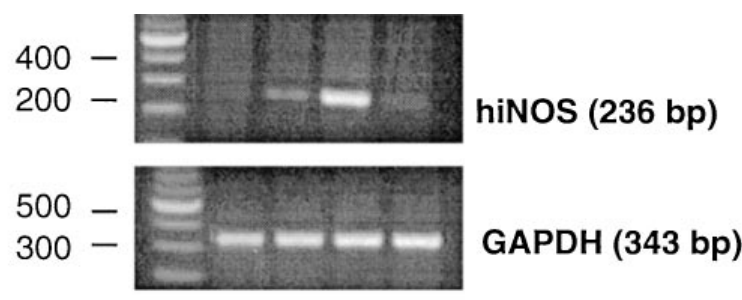

$\begin{array}{lllll}\mathrm{IL}-1 \beta(75 \text { units } / \mathrm{ml}) & - & - & + & - \\ \operatorname{IFN}-\gamma(750 \mathrm{units} / \mathrm{ml}) & - & + & + & + \\ \operatorname{TNF}(50 \mathrm{ng} / \mathrm{ml}) & - & + & - & + \\ \operatorname{LPS}(10 \mu \mathrm{g} / \mathrm{ml}) & - & + & - & + \\ \operatorname{IRAP}(5 \mu \mathrm{g} / \mathrm{ml}) & - & - & - & +\end{array}$

Figure 4. Effects of macrophage depletion on iNOS expression and nitrite production by human islets. Isolated human islets were cultured for $7 \mathrm{~d}$ at $24^{\circ} \mathrm{C}$ to deplete resident macrophages. The islets $(150 / 400 \mu \mathrm{l}$ of complete CMRL-1066) were then treated for $40 \mathrm{~h}$ with $75 \mathrm{U} / \mathrm{ml} \mathrm{IL}-1,750 \mathrm{U} / \mathrm{ml} \mathrm{IFN}-\gamma$, $50 \mathrm{ng} / \mathrm{ml} \mathrm{TNF}-\alpha, 10 \mu \mathrm{g} / \mathrm{ml}$ LPS, and $5 \mu \mathrm{g} / \mathrm{ml}$ human recombinant IRAP at $37^{\circ} \mathrm{C}$ as indicated. $(A)$ After the treatment period, the culture media were removed for nitrite determination, and $(B)$ the islets were isolated and iNOS expression was determined by Western blot analysis. $(C)$ Macrophage-depleted human islets ( 80 islts/400 $\mu$ l of complete CMRL-1066) were cultured for $8 \mathrm{~h}$ with the indicated concentrations of cytokines and LPS. The islets were isolated and iNOS mRNA expression was determined by RT-PCR. Nitrite data are the mean \pm SEM of four independent experiments from four separate human islet isolations. Western blot data are representative of four independent experiments from four separate human islet isolations, and RT-PCR is representative of two independent experiments from two separate human islet isolations.

of macrophages in human islets was determined in a doubleblind fashion by immunofluorescent microscopy using antisera specific for human macrophages (mouse anti-human CD68). Freshly isolated human islets contain 5.5 \pm 1.1 CD68-positive macrophages $/ 100$ islet cells, while islets cultured for $7 \mathrm{~d}$ at $24^{\circ} \mathrm{C}$ contain 0.77 \pm 0.42 CD68-positive macrophages/100 islet cells. These results, which are the average \pm SEM of two experiments containing two replicates per condition, provide evidence that a $7-\mathrm{d}$ culture at $24^{\circ} \mathrm{C}$ results in the depletion of $>80 \%$ of resident islet macrophages, although it does not result in the complete loss of this islet cell population.

Isoform(s) of IL-1 expressed in human islets in response to $T N F+L P S+I F N-\gamma$. Recently, IL-1 $\alpha$ mRNA expression has been detected in mononuclear leukocytes purified from islets isolated from nonobese diabetic (NOD) mice recently diagnosed with autoimmune diabetes $(13,17)$. Using RT-PCR and semiquantitative PCR, we have examined the effects of TNF + LPS + IFN- $\gamma$ on the time-dependent expression of IL- $1 \alpha$ and IL-1 $\beta$ mRNA, and quantitated the levels of each mRNA species in human islets. TNF + LPS + IFN- $\gamma$ stimulate the timedependent expression of both IL- $1 \alpha$ and IL-1 $\beta$ mRNA that is first apparent at $4 \mathrm{~h}$ and appears to be maximal after a $12-\mathrm{h}$ incubation (Fig. $5 A$ ). Neither IL- $1 \alpha$ nor IL-1 $\beta$ expression is de- tected in untreated control human islets. The levels of IL-1 $\alpha$ and IL-1 $\beta$ mRNA which accumulate in response to TNF + LPS + IFN- $\gamma$ were directly compared by semiquantitative PCR. As shown in Fig. $5 B$, TNF + LPS + IFN- $\gamma$ stimulate a nearly twofold increase in the levels of IL-1 $\beta$ as compared with IL-1 $\alpha$ mRNA after a 12-h incubation. Although both isoforms of IL-1 are expressed, these results suggest that the predominate isoform expressed in human islets in response to a 12-h incubation with TNF + LPS + IFN- $\gamma$ is IL- $1 \beta$. In further support for an important role of IL-1 $\beta$ in the initiation of autoimmune diabetes, Cailleau et al. (18) have shown recently that neutralizing antibodies specific for IL-1 $\beta$ prevent cyclophosphamide-induced diabetes in the NOD mouse.

The effects of a $7-\mathrm{d}$ culture at $24^{\circ} \mathrm{C}$ on IL- $1 \alpha$ and IL- $1 \beta$ mRNA accumulation in response to a 4,8 , or $12 \mathrm{~h}$ of incubation with TNF + LPS + IFN- $\gamma$ have also been examined. Macrophage-depleted human islets do not express IL-1 $\alpha$ or IL-1 $\beta$ mRNA in response to TNF + LPS + IFN- $\gamma$ (data not shown). The lack of IL-1 expression by human islets that have been depleted of resident macrophages provides additional evidence that resident macrophages may be one islet cellular source of IL-1.

Identification of resident macrophages as the human islet 


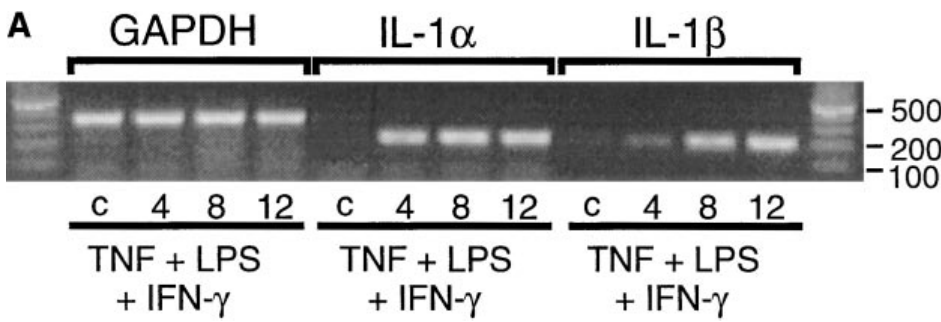

Figure 5. Time course and isoform of IL-1 expressed in human islets. (A) Human islets were cultured with $50 \mathrm{ng} / \mathrm{ml} \mathrm{TNF-} \alpha, 750 \mathrm{U} / \mathrm{ml} \mathrm{IFN}-\gamma$, and $10 \mu \mathrm{g} / \mathrm{ml}$ LPS for 4,8 , and $12 \mathrm{~h}$ at $37^{\circ} \mathrm{C}$. The islets were isolated and IL- $1 \alpha$ and IL-1 $\beta$ mRNA accumulation was determined by RT-PCR. (B) The levels of IL- $1 \alpha$ and IL-1 $\beta$ mRNA after a 12-h incubation of human islets with TNF- $\alpha+$ LPS + IFN- $\gamma$ were determined by semiquantitative PCR. IL- $1 \alpha$ and IL- $1 \beta$ mRNA accumulation is expressed as a percentage of GAPDH mRNA (internal control). Data are representative of two independent experiments from two individual human islet isolations.

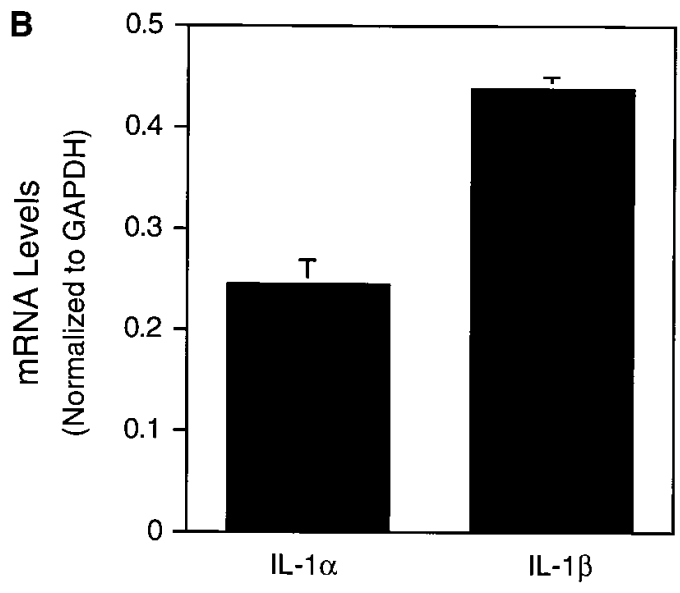

cellular source of IL-1. To determine the cellular source of IL-1, human islets were cultured for $4 \mathrm{~h}$ with TNF + LPS + IFN- $\gamma$. The islets were isolated, dispersed into individual cells, fixed onto slides, and then stained for IL-1 and the macrophage surface marker CD68. As shown in Fig. 6, TNF + LPS + IFN- $\gamma$ stimulate IL- $1 \beta$ expression in a limited number of islet cells as evidenced by the punctate red fluorescence (Fig. 6, middle right), and IL-1 $\beta$ expression localizes with CD68 positive macrophages (Fig. 6, green fluorescence), as evidenced by the yellow fluorescence after double exposure (Fig. 6, bottom right). Importantly, not every CD68-positive macrophage stains positive for IL-1 $\beta$ (5.5 \pm 1.07 CD68-positive macrophages/100 islet cells as compared with 3.6 \pm 0.7 IL-1 $\beta$-positive cells/100 islet cells). However, IL-1 $\beta$ was not detected in any islet cell type other than CD68-positive macrophages. In addition, IL-1 $\beta$ expression is not detected in untreated islet endocrine or nonendocrine cells although a similar number of CD68-positive macrophages were detected, as compared with $\mathrm{TNF}+$ LPS + IFN- $\gamma$-treated human islets (Fig. 6, left). In addition, cross-reactivity of secondary antisera and nonspecific primary antisera of the same species was not observed. These findings provide direct evidence that CD68-positive macrophages are the islet cellular source of IL-1 $\beta$ in response to $\mathrm{TNF}+\mathrm{LPS}+\mathrm{IFN}-\gamma$.

Mechanisms of IL-1 release in human islets. Recent studies suggest that nitric oxide is required for the release of biologically active IL-1 from mouse peritoneal exudate cells and RAW 264.7 macrophages (19). iNOS inhibitors NMMA and AG prevent LPS + IFN- $\gamma$ - and LPS-induced IL-1 release and nitric oxide production by mouse peritoneal exudate cells and RAW 264.7 cells, respectively (19). If nitric oxide participates in IL-1 release by resident islet macrophages, then the inhibition of nitric oxide production should prevent TNF + LPS + IFN- $\gamma$-induced iNOS expression by human islets. As shown in Fig. 7, AG (and NMMA, data not shown) completely prevents $\mathrm{TNF}+\mathrm{LPS}+\mathrm{IFN}-\boldsymbol{\gamma}$-induced nitrite formation, but does not inhibit iNOS expression by human islets. However, IRAP prevents TNF + LPS + IFN- $\gamma$-induced iNOS expression and nitrite formation. These results indicate that nitric oxide is not required for TNF + LPS + IFN- $\gamma$-induced IL- 1 release in human islets. As a control, the ability of AG to attenuate IL-1 $\beta+$
IFN- $\gamma$-induced nitrite production without inhibiting iNOS expression by human islets is also shown (Fig. 7). These findings indicate that the intraislet release of IL- 1 in human islets is by a mechanism that is independent of nitric oxide production.

Several studies have shown that macrophage damage or death (either by apoptosis or necrosis) results in the release of IL-1 (20, 21). To determine if cellular damage participates in intraislet IL-1 release, the individual effects of IFN- $\gamma$ on iNOS expression by human islets physically dispersed into individual cells were examined. Islet dispersion involves the treatment of intact islets with trypsin, an experimental manipulation that results in the destruction of $\sim 5 \%$ of islet cells (based on trypan blue exclusion, data not shown). Recently, we have shown that macrophage damage after the physical dispersion of rat islets into individual cells results in the release of IL-1 to levels that are sufficient to stimulate iNOS expression in the presence of exogenously added IFN- $\gamma$ (22). Treatment of dispersed human islet cells with IFN- $\gamma$ results in the expression of iNOS as determined by Western blot analysis (Fig. $8 \mathrm{~A}$ ). IRAP completely prevents IFN- $\gamma$-induced iNOS expression, indicating that physical dispersion of human islets into individual cells results in the endogenous release of IL-1. In addition, antisera specific for IL- $1 \alpha$ and IL- $1 \beta$ also significantly attenuate iNOS expression by dispersed islet cells stimulated by IFN- $\gamma$ (data not shown). To determine if resident macrophages are a cellular source of IL-1, the effects of macrophage depletion on IFN$\gamma$-induced iNOS expression by dispersed human islet cells were examined (Fig. $8 \mathrm{~B}$ ). Although IFN- $\gamma$ stimulates the expression of iNOS by freshly isolated dispersed human islet cells, IFN- $\gamma$ does not induce the iNOS expression by dispersed islet cells prepared from macrophage-depleted human islets. In addition, the 7- $\mathrm{d}$ culture at $24^{\circ} \mathrm{C}$ does not inhibit $\beta$ cell expression of iNOS in response to IL- $1+$ IFN- $\gamma$. These results suggest that cellular damage may be one mechanism that leads to the release of IL-1 in human islets by resident macrophages.

In this study evidence is provided in support of the hypothesis that activation of resident macrophages in human islets results in the impairment of $\beta$ cell function by a mechanism that is dependent on the intraislet release of IL-1. The inhibitory effects of resident macrophage activation on $\beta$ cell function appear to be mediated by the expression of iNOS and the in- 


\section{Control}

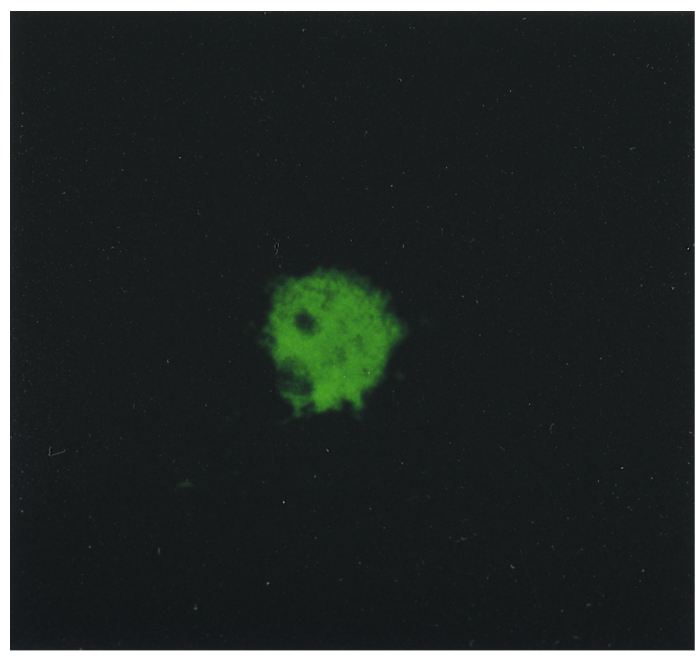

Mac

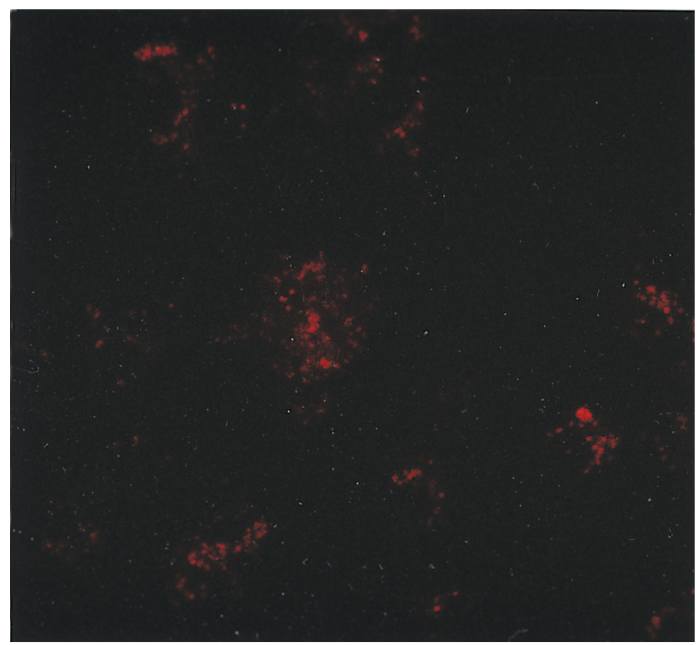

IL-1 $\beta$

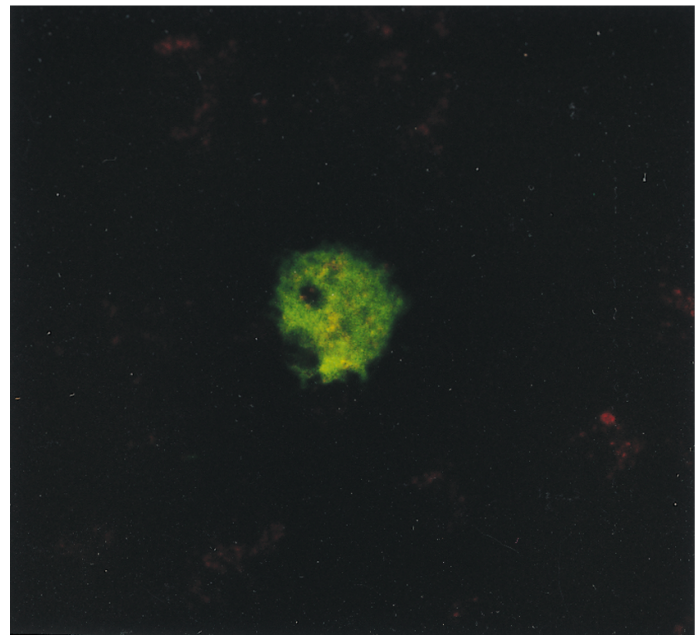

TNF + LPS + IFN- $\gamma$
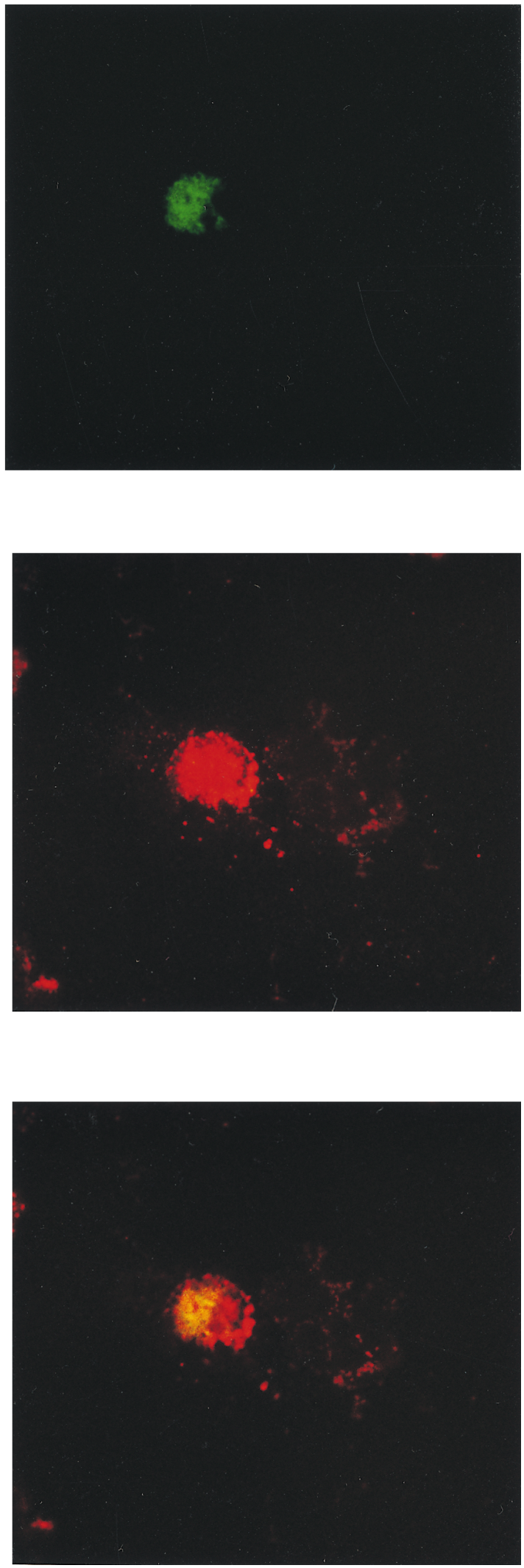

Figure 6. Immunohistochemical localization of resident macrophages as the human islet cellular source of IL-1. Human islets were untreated (Control) or treated for $4 \mathrm{~h}$ with $50 \mathrm{ng} / \mathrm{ml} \mathrm{TNF}+10 \mu \mathrm{g} / \mathrm{ml} \mathrm{LPS}+750 \mathrm{U} / \mathrm{ml} \mathrm{IFN}-\gamma$. The islets were isolated, dispersed into individual cells, and plated onto slides by cytospin. IL-1 $\beta$ was identified using goat anti-human IL-1 $\beta$ and CY3-conjugated donkey anti-goat secondary antisera (red 

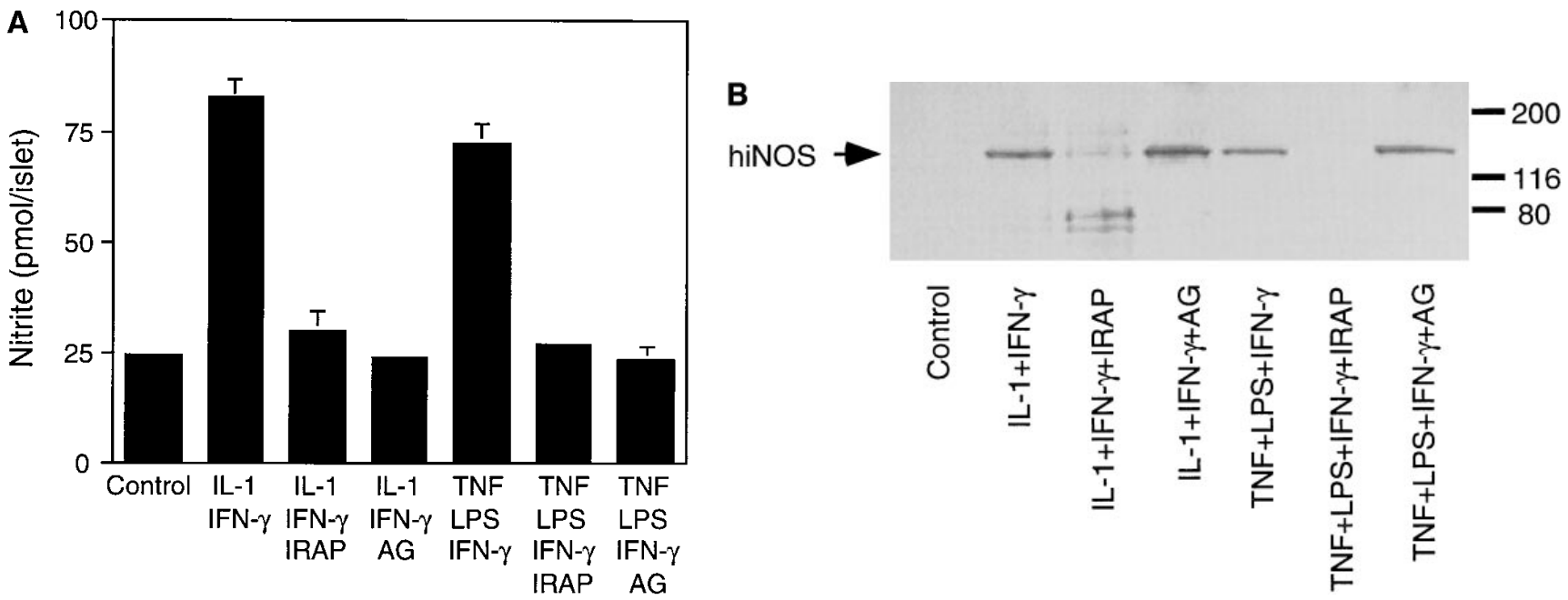

Figure 7. Effects of AG on TNF + LPS + IFN- $\gamma$-induced IL-1 release in human islets. Human islets (150/400 $\mu$ l of complete CMRL-1066) were cultured for $40 \mathrm{~h}$ at $37^{\circ} \mathrm{C}$ with $75 \mathrm{U} / \mathrm{ml} \mathrm{IL}-1 \beta, 750 \mathrm{U} / \mathrm{ml} \mathrm{IFN}-\gamma, 50 \mathrm{ng} / \mathrm{ml} \mathrm{TNF}-\alpha, 10 \mu \mathrm{g} / \mathrm{ml} \mathrm{LPS}, 5 \mu \mathrm{g} / \mathrm{ml}$ IRAP, and $1 \mathrm{mM}$ AG as indicated. $(A)$ The culture media were removed for nitrite determinations, and $(B)$ the islets were isolated for Western blot detection of iNOS expression. The results are representative of three independent experiments from three separate human islet isolations.

creased production of nitric oxide. Aminoguanidine attenuates the inhibitory effects of resident macrophage activation on insulin secretion by human islets, and IRAP prevents both the inhibitory effects of TNF + LPS + IFN- $\gamma$ on insulin secretion and the stimulatory effects on iNOS expression and nitric oxide production. These results suggest that nitric oxide, produced by human islet macrophages, does not mediate $\beta$ cell damage. However, the release of IL-1 in islets followed by IL-1 + IFN- $\gamma$-induced iNOS expression by $\beta$ cells results in $\beta$ cell damage. Islets contain several nonendocrine cells that are potential sources of IL-1. These include endothelial cells, fibroblasts, macrophages, and dendritic cells. In rat islets, endothelial cells appear to "ball up" and are extruded after a 48-h culture and fibroblasts are normally found in only a thin capsule around islets and this capsule is lost during isolation (Bonner-Weir, S., personal communication). In this study, human islets were cultured for $72 \mathrm{~h}$ before initiation of experiments, or conditions under which endothelial cells would be extruded from islets. We believe that macrophages are the source of IL-1 in human islets, as culture conditions known to deplete islets of lymphoid cells prevent TNF + LPS + IFN- $\gamma$-induced iNOS and IL-1 expression and nitrite production by human islets. In addition, immunohistochemical colocalization of IL-1 with the macrophage surface marker CD68 provides direct evidence that resident macrophages are the islet cellular source of IL-1.

It is clear that human macrophages express iNOS (23-25). However, it has been difficult to demonstrate increased production of nitric oxide by activated human macrophages to levels comparable to the levels produced by rodent macrophages (26). Our studies suggest that resident human mac- rophage production of nitric oxide does not inhibit $\beta$ cell function. However, macrophage activation and cytokine release, followed by cytokine-induced iNOS expression by target $\beta$ cells, may be one mechanism by which resident human macrophages mediate tissue damage during the development of IDDM.

These studies also raise the possibility that resident islet macrophages may participate in the initial destruction of $\beta$ cells leading to the activation of an immune process resulting in the continued destruction of remaining $\beta$ cells. The precipitating events that lead to initial $\beta$ cell destruction during the development of IDDM are unknown (27). However, environmental factors appear to play an important role. Evidence for environmental factors comes from the relatively low concordance of IDDM between identical twins ( $<40 \%)$ (28). Environmental factors that have been implicated in the development of IDDM include chemical toxins or viral infections (29, 30). Several hypotheses have suggested that environmental factors either "trigger" $\beta$ cell death by directly targeting $\beta$ cells, or contribute to $\beta$ cell autoimmunity by unknown mechanisms (31). Our findings provide biochemical evidence to support a role for resident macrophages as a potential target for an environmental insult that may trigger the initiation of IDDM in genetically predisposed individuals. Viral infections are known stimuli for macrophage activation and cytokine release $(32,33)$, and cellular damage is one mechanism associated with IL-1 release by macrophages $(20,21)$. In addition, we have shown recently that dsRNA, the active component of a viral infection that stimulates antiviral activities in infected cells, stimulates IL-1 release by mouse macrophages (34). In

Figure 6 legend (Continued)

fluorescence), and macrophages were identified using mouse anti-human macrophage (CD68) and FITC-conjugated donkey anti-mouse secondary antisera (red fluorescence). Colocalization of IL-1 $\beta$ - and CD68-positive macrophages is shown by yellow fluorescence after double exposure. Results are representative of two individual experiments. 
A
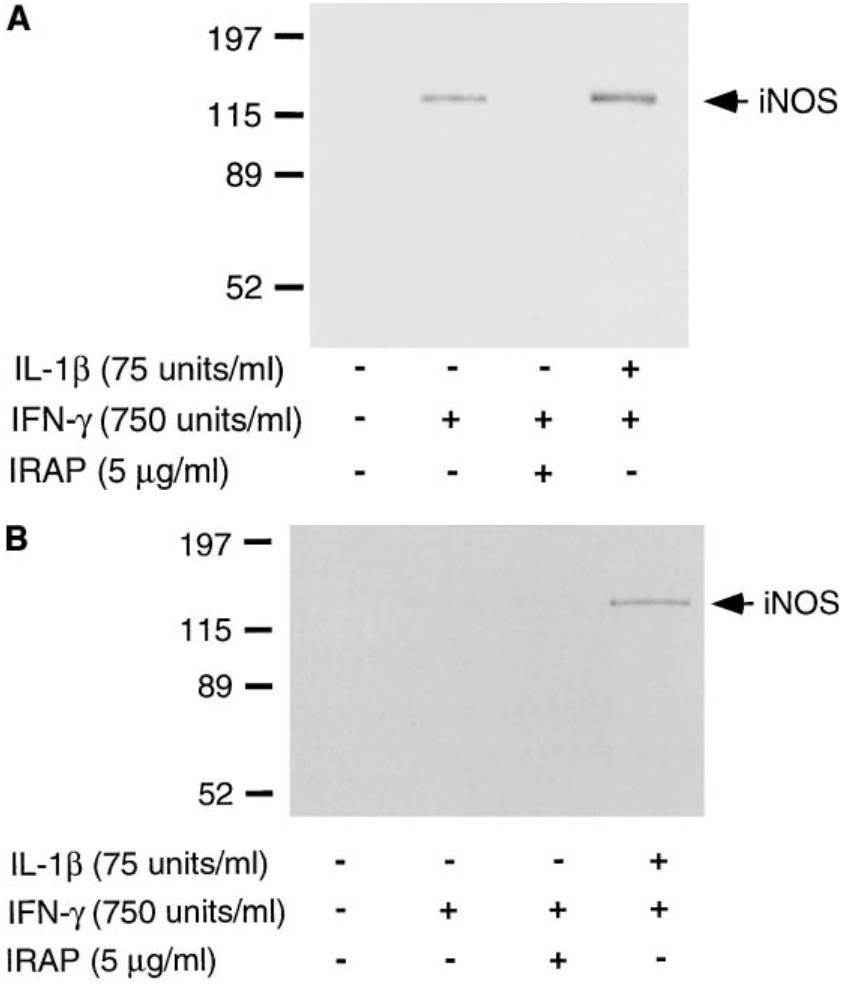

Figure 8. Endogenous release of IL-1 during islet dispersion is required for IFN- $\gamma$-induced iNOS expression. Human islets were dispersed into individual cells from either freshly isolated $(A)$, or after a 7 -d culture at $24^{\circ} \mathrm{C}(B)$, aliquoted $(120,000$ cells $/ 400 \mu$ l of complete CMRL-1066), and then cultured for $40 \mathrm{~h}$ with the indicated concentrations of IL-1 $\beta$, IFN- $\gamma$, and IRAP. The islet cells were isolated and iNOS expression was detected by Western blot analysis. Results are representative of three independent experiments for freshly isolated human islet, and two independent experiments for macrophagedepleted human islets.

this study, we show that a combination of TNF + LPS + IFN- $\gamma$ inhibits $\beta$ cell function by a mechanism that is dependent on the intraislet release of IL-1 and the production of nitric oxide. The islet cellular source of IL-1 is believed to be resident macrophages, and cellular damage appears to be one mechanism by which resident macrophages release IL-1 in human islets. iNOS expression by human $\beta$ cells requires IFN- $\gamma$ in addition to IL-1. T cells are the most likely cellular source of IFN- $\gamma$. Viral infection would be expected to stimulate macrophage release of IL-1, and to stimulate T cell migration (to islets) and activation resulting in the release of IFN- $\gamma$. The release of these cytokines in the microenvironment of the islet would be sufficient to stimulate iNOS expression by $\beta$ cells, resulting in $\beta$ cell damage and the release of potential autoantigens or $\beta$ cell neoantigens leading to autoimmunity against the $\beta$ cell.

\section{Acknowledgments}

We would like to thank Colleen Kelly for expert technical assistance, Denise Dorsey for assistance with immunohistochemistry of human islets, and Dr. Paul Lacy for many helpful discussions and advice during the course of this work. We would also like to thank the Islet Isolation Core Facility and the Diabetes Research and Training Center at Washington University School of Medicine for supplying human islets and performing insulin RIAs, and the Diabetes Research Institute at the University of Miami for supplying human islets.

This work was supported by research grants from Alteon Inc., The Tobacco Research Council, The National Institutes of Health (DK-52194), and a Career Development Award from the Juvenile Diabetes Foundation International (J.A. Corbett).

\section{References}

1. Lacy, P.E. 1994. The intraislet macrophage and type I diabetes. Mount Sinai J. Med. 61:170-174.

2. Schreiner, G.F., W. Fly, E. Brunt, K. Korber, and J.B. Lefkowith. 1988 Essential fatty acid depletion of renal allografts and prevention of rejection. Science. 240:1032-1033.

3. Wright, J.R., J.B. Lefkowith, G. Schreiner, and P.E. Lacy. 1988. Essential fatty acid deficiency prevents multiple low-dose streptozotocin-induced diabetes in CD-1 mice. Proc. Natl. Acad. Sci. USA. 85:6137-6141.

4. Lefkowith, J.B., G. Schreiner, J. Cormier, E.S. Handler, H.K. Driscoll, D. Greiner, J.P. Mordes, and A.A. Rossini. 1990. Prevention of diabetes in the BB rat by essential fatty acid-deficiency. Relationship between physiological and biochemical changes. J. Exp. Med. 171:729-743.

5. Oschilewski, U., U. Kiesel, and H. Kolb. 1985. Administration of silica prevents diabetes in BB rats. Diabetes. 34:197-199.

6. Lacy, P.E., and E.H. Finke. 1991. Activation of intraislet lymphoid cells causes destruction of islet cells. Am. J. Pathol. 138:1183-1190.

7. Corbett, J.A., and M.L. McDaniel. 1995. Intraislet release of IL-1 inhibits $\beta$ cell function by inducing $\beta$ cell expression of iNOS. J. Exp. Med. 181:559-568.

8. Corbett, J.A., G. Kwon, M. Marino, C.P. Rodi, P.M. Sullivan, and M.L. McDaniel. 1996. Tyrosine kinase inhibitors prevent cytokine-induced expression of iNOS and COX-2 by human islets of Langerhans. Am. J. Physiol. 39: C1581-C1587.

9. Corbett, J.A., M.A. Sweetland, J.L. Wang, J.R. Lancaster, Jr., and M.L. McDaniel. 1993. Nitric oxide mediates cytokine-induced inhibition of insulin secretion by human islets of Langerhans. Proc. Natl. Acad. Sci. USA. 90:17311735 .

10. Ono, J., R. Takaki, and M. Fukuma. 1977. Preparation of single cells from pancreatic islets of adult rat by the use of dispase. Endocrinol. Jpn. 24: 265-270.

11. Green, L.C., D.A. Wagner, J. Glogowski, P.L. Skipper, J.S. Wishnok, and S.R. Tannenbaum. 1982. Analysis of nitrate, nitrite, and $\left[{ }^{15} \mathrm{~N}\right]$ nitrate in biological fluids. Anal. Biochem. 126:131-138.

12. Kennedy, M.K., D.S. Torrance, K.S. Picha, and K.M. Mohler. 1992. Analysis of cytokine mRNA expression in the central nervous system of mice with experimental autoimmune encephalomyelitis reveals that IL-10 mRNA correlates with recovery. J. Immunol. 149:2496-2505.

13. Rabinovitch, A., W.L. Saurez-Pinzon, O. Sorensen, R.C. Bleackley, and R.F. Power. 1995. IFN- $\gamma$ gene expression in pancreatic islet-infiltrating mononuclear cells correlates with autoimmune diabetes in nonobese diabetic mice. $J$. Immunol. 154:4874-4882.

14. Eizirik, D.L., S. Sandler, N. Welsh, M. Cetkovic-Cvrlje, A. Nieman, D.A. Geller, D.G. Pipeleers, K. Bendtzen, and C. Hellerstrom. 1994. Cytokines suppress human islet function irrespective of their effects on nitric oxide generation. J. Clin. Invest. 93:1968-1974.

15. Corbett, J.A., R.G. Tilton, K. Chang, K.S. Hasan, Y. Ido, J.L. Wang, M.A. Sweetland, J.R. Lancaster, Jr., J.R. Williamson, and M.L. McDaniel. 1991. Aminoguanidine, a novel inhibitor of nitric oxide formation, prevents diabetic vascular dysfunction. Diabetes. 41:552-556.

16. Misko, T.P., W.M. Moore, T.P. Kasten, G.A. Nickols, J.A. Corbett, R.G. Tilton, M.L. McDaniel, J.R. Williamson, and M.G. Currie. 1993. Selective inhibition of the inducible isoform of nitric oxide synthase by aminoguanidine. Eur. J. Pharmacol. 233:119-125.

17. Rabinovitch, A., W.L. Saurez-Pinzon, O. Sorensen, and R.C. Bleackley. 1996. Inducible nitric oxide synthase (iNOS) in pancreatic islets of nonobese diabetic mice. Identification of iNOS expression cells and relationship to cytokines expressed in the islets. Endocrinology. 137:2093-2099.

18. Cailleau, C., A. Diu-Hercend, E. Ruuth, R. Westwood, and C. Carnaud. 1997. Treatment with neutralizing antibodies specific for IL-1 $\beta$ prevents cyclophosphamide-induced diabetes in nonobese diabetic mice. Diabetes. 46:937940.

19. Hill, J.R., J.A. Corbett, G. Kwon, C.A. Marshall, and M.L. McDaniel. 1996. Nitric oxide regulates interleukin-1 bioactivity released from murine macrophages. J. Biol. Chem. 271:22672-22678.

20. Hogquist, K.A., M.A. Nett, E.R. Unanue, and D.D. Chaplin. 1991. Interleukin-1 is processed and released during apoptosis. Proc. Natl. Acad. Sci. USA. 88:8485-8489.

21. Zychlinsky, A., C. Fitting, J.M. Cavaillon, and P.J. Sansonetti. 1994. Interleukin-1 is released by murine macrophages during apoptosis induced by Shigella flexneri. J. Clin. Invest. 94:1328-1332.

22. Heitmeier, M.R., A.L. Scarim, and J.A. Corbett. 1997. IFN- $\gamma$ increases 
the sensitivity of islets of Langerhans for iNOS expression induced by IL-1. $J$. Biol. Chem. 272:13653-13661.

23. Nicholson, S., M.G. Bonecini-Almeida, L.E. Silva, Jr., C. Nathan, Q.-W. Xie, R. Mumford, J.R. Weidner, J. Calaycay, J. Geng, N. Boechat, et al. 1996. Inducible nitric oxide synthase in pulmonary alveolar macrophages from patients with tuberculosis. J. Exp. Med. 183:2293-2302.

24. Guo, F.H., H.R. DeRaeve, T.W. Rice, D.J. Stuehr, F.B. Thunnissen, and S.C. Erzurum. 1995. Continuous nitric oxide synthesis by inducible nitric oxide synthase in normal human airway epithelium in vivo. Proc. Natl. Acad. Sci. USA. 92:7809-7813.

25. Watkins, S.C., W. Macaulay, D. Turner, R. Kang, H.E. Rubash, and C.H. Evans. 1997. Identification of inducible nitric oxide synthase in human macrophages surrounding loosened hip prostheses. Am. J. Pathol. 150:11991206.

26. Albina, J.E. 1995. On the expression of nitric oxide synthase by human macrophages. Why no NO? J. Leukocyte Biol. 58:643-649.

27. Benoist, C., and D. Mathis. 1997. Cell death mediators in autoimmune diabetes. No shortage of suspects. Cell. 89:1-3.
28. Barnett, A.H., C. Eff, R.D. Leslie, and D.A. Pyke. 1981. Diabetes in identical twins: a study of 200 pairs. Diabetologia. 20:87-93.

29. Bach, J.-F. 1994. Insulin-dependent diabetes mellitus as an autoimmune disease. Endocrinol. Rev. 15:516-541.

30. Yoon, J.W. 1991. Role of viruses in the pathogenesis of IDDM. Ann. Med. 23:437-445.

31. Nerup, J., and A. Lernmark. 1981. Autoimmunity in insulin-dependent diabetes mellitus. Am. J. Med. 70:135-141.

32. Peschke, T., A. Bender, M. Nain, and D. Gemsa. 1993. Role of macrophage cytokines in influenza A virus infections. Immunobiology. 189:340 355.

33. Henke, A., C. Mohr, C. Graebner, A. Stelzner, M. Nain, and D. Gernsa. 1992. Coxsackie virus B3-induced production of tumor necrosis factor-alpha, IL-1 beta and IL-6 in human monocytes. J. Immunol. 148:2270-2277.

34. Heitmeier, M.A., A.L. Scarim, and J.A. Corbett. 1998. Double-stranded RNA-induced iNOS expression and IL-1 release by murine macrophages requires NF-kB activation. J. Biol. Chem. 273:15301-15307. 